\title{
A revision of the chameleon species Chamaeleo pfeili Schleich (Squamata; Chamaeleonidae) with description of a new material of chamaeleonids from the Miocene deposits of southern Germany
}

\author{
ANDREJ ČERŇANSKÝ
}

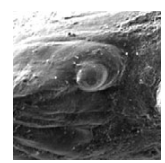

\begin{abstract}
A revision of Chamaeleo pfeili Schleich is presented. The comparisons of the holotypic incomplete right maxilla with those of new specimens described here from the locality Langenau (MN 4b) and of the Recent species of Chamaeleo, Furcifer and Calumma is carried out. It is shown that the type material of C. pfeili and the material described here lack autapomorphic features. Schleich based his new species on the weak radial striations on the apical parts of bigger teeth. However, this character is seen in many species of extant chameleons, e.g. Calumma globifer, Furcifer pardalis and C. chamaeleon. For this reason, the name C. pfeili is considered a nomen dubium. This paper provides detailed descriptions and taxonomy of unpublished material from Petersbuch 2 (MN 4a) and Wannenwaldtobel (MN 5/6) in Germany. The material is only fragmentary and includes jaw bits. The morphology of the Petersbuch 2 material is very similar to that of the chameleons described from the Czech Republic. $\bullet$ Key words: Chamaeleo pfeili, nomen dubium, morphology, Wannenwaldtobel, Petersbuch 2, Langenau, Neogene.
\end{abstract}

ČERŇANSKÝ, A. 2011. A revision of the chameleon species Chamaeleo pfeili Schleich (Squamata; Chamaeleonidae) with description of a new material of chamaeleonids from the Miocene deposits of southern Germany. Bulletin of Geosciences 86(2), 275-282 (6 figures). Czech Geological Survey, Prague. ISSN 1214-1119. Manuscript received February 11, 2011; accepted in revised form March 21, 2011; published online April 20, 2011; issued June 20, 2011.

Andrej Čerñanský, Faculty of Natural Sciences, Comenius University in Bratislava, Department of Geology and Paleontology, Mlynská dolina, 84215 Bratislava, Slovakia; cernansky.paleontology@gmail.com

The family Chamaeleonidae includes extant species from Africa, Madagascar, southwest Asia and the Mediterranean region of Europe - Iberian Peninsula, Peloponneses and several islands (Estes 1983, Gasc et al. 1997). During the Miocene period, this family had a more northerly distribution. The oldest representatives are described from the locality Merkur in the Czech Republic (MN 3a; Fejfar \& Schleich 1994, Čerňanský 2010) and Wintershof in Germany (Moody \& Roček 1980). The youngest record in central Europe comes from the Swiss locality Ornberg in the Molasse Basin (MN 6; Bolliger 1992). Several fossil species of the genus Chamaeleo have been described from the Miocene period in Europe: C. caroliquarti Moody \& Roček, 1980 (referred to as nomen dubium in Čerňanský 2010; MN 4, the Czech Republic and Germany), C. bavaricus Schleich, 1983 (MN 5, Germany), C. pfeili Schleich, 1984 (MN 4b, Germany), C. simplex Schleich, 1994 (MN 5, Germany), C. sulcodentatus Schleich, 1994 (MN 5, Germany) and C. andrusovi Čerňanský, 2010 (MN 4, the Czech Republic). The recent species $C$. chamaeleon has been reported from the Holocene of Spain (Talavera \& Sanchiz 1983).

The German chameleons are well-known (e.g. Moody
\& Roček 1980; Schleich 1983, 1984, 1994; Mörs 2002; Böhme 2003, 2010), one of which, C. pfeili, was named in 1984 by Schleich based on several fragments of maxillae. The holotype is represented by a fragment of the left maxilla, BSP 1979 XV 469. Several other fragments of maxilla (BSP 1979 XV 470; BSP 1979 XV 471; and BSP 1979 XV 472) were included to the paratypic material. According to Schleich (1984), the most significant feature is that the apical parts of the bigger teeth bear weak radial striations. However, comparisons with extant chameleons were limited, which prompts the present reevaluation of the validity of the species.

Additionally, new material of chameleons has been recovered from three German additional Miocene localities: Petersbuch 2, MN 4a; Langenau, MN 4b; and Wannenwaldtobel 2, MN 5/6 (Fig. 1). Here, the occurrence of chameleons was known (Sach 1999, Böhme 2010), but the material has never been described or illustrated. Therefore, the aims of this paper are: 1) the description of the material of chameleons from the Miocene localities in southern Germany; and 2) a taxonomic revision of the species Chamaeleo pfeili Schleich, 1984. 


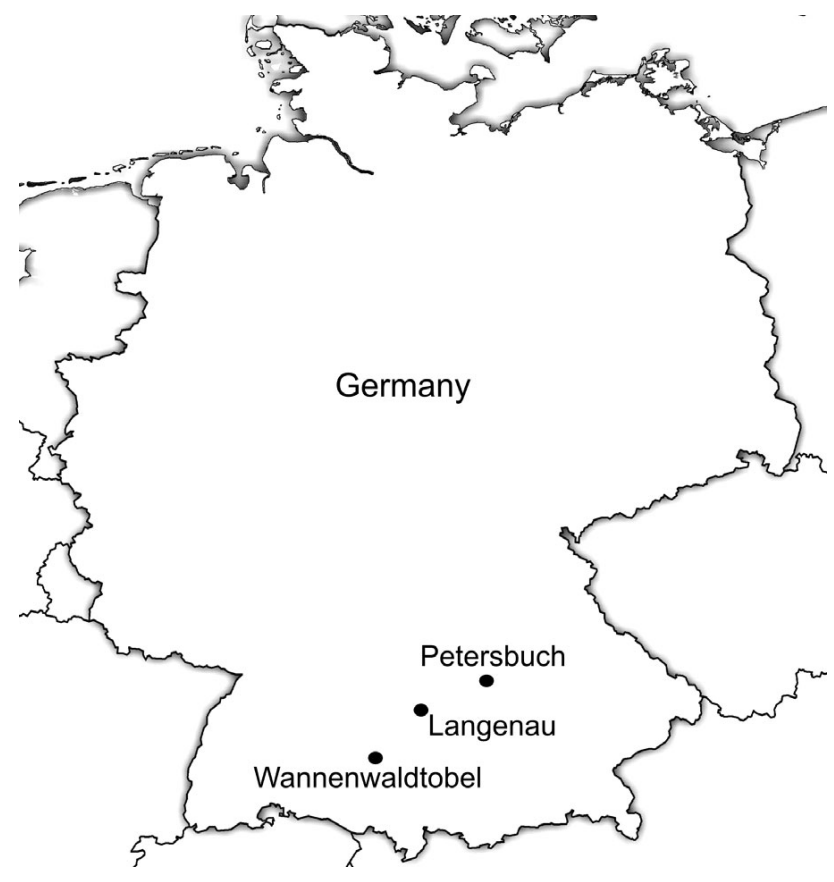

Figure 1. Location of the three Neogene German localities studied in this paper.

\section{Material and methods}

The material presented here derives from three German Miocene localities (Fig. 1): Petersbuch 2, MN 4a; Langenau, MN 4b; and Wannenwaldtobel 2, MN 5/6. All material was collected by screen-washing or surface prospecting. The fossils are housed in the Staatliches Museum für Naturkunde Stuttgart in Germany and are prefixed by the abbreviation SMNS. These comprise isolated elements including maxilla and dentary finds. The osteological terminology of the dentary follows that of Čerňanský (2010). The following specimens of extant species of chameleons of different ontogenetic stages deposited in the collections of the Department of Ecology, Comenius University in Bratislava, Faculty of Natural Sciences, have been used for comparisons: Chamaeleo calyptratus - DE 65, DE 74-77; C. chamaeleon - DE 66; Furcifer pardalis - DE 80-81; Calumma globifer - DE 82-85. Comparisons based on the literature included descriptions of extant species from Madagascar (Rieppel \& Crumly 1997). The extant specimens (Figs 3, 4) were photographed using a scanning electron microscope (SEM). Chamaeleo calyptratus is a large arboreal species that ranges from Asir Province, southwestern Saudi Arabia, to Aden, Yemen, where it lives on high, dry plateaus up to $2800 \mathrm{~m}$ and in foothills, forests, low-elevation maize fields, and inland river valleys (Fritz \& Schütte 1987, Meerman \& Boomsma 1987, Zari 1993, Showler 1995, Schmidt 2001). This taxon has been introduced in Florida (Krysko et al. 2004). Chamaeleo calyptratus feeds primarily on insects, but its large size enables it to occasionally prey on small mammals and fledgling birds. Chamaeleo chamaeleon is an insectivorous, medium-sized lizard. It has the broadest distribution of all chameleon species, found from Morocco and the southern Iberian Peninsula over the whole of North Africa, to the Near East, Greece, Turkey, Cyprus, and Southern Arabia and - perhaps with a gap in Iran - to India and Sri Lanka (Hillenius 1959, 1978; Ondrias 1968; Chondropoulos 1986). The species Furcifer pardalis, with a typical length of around $450 \mathrm{~mm}$, lives in the eastern and northern parts of Madagascar in a tropical forest biome. Additionally, it has been introduced to Rénuion and Mauritius (Glaw \& Vences 1994, Andreone et al. 2005). Calumma globifer is endemic to Madagascar, locally distributed in the eastern rainforest (Brygoo 1971, Glaw \& Vences 1994). It is a large, arboreal species that can grow up to $365 \mathrm{~mm}$ (Brygoo 1971).

\section{Geological settings}

1. Petersbuch 2: This locality represents a karstic fissure filling in the Upper Jurassic. It is a former quarry east of Petersbuch near Eichstätt, Bavaria, South Germany

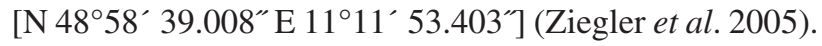
The Petersbuch 2 fissure, which was discovered in 1977, contains an exceptionally rich vertebrate fauna, detailed descriptions of which were published in the years following, e.g., snakes (Szyndlar \& Schleich 1993), a cordylid lizard (Kosma 2004) and many mammals (e.g. Heizmann 1983; Ziegler 1985, 1989, 1990; Wu 1993; Fejfar et al. 1998). Petersbuch is the oldest central European locality yielding modern cricetids (e.g. Democricetodon) and is therefore placed in MN4a. The stratigraphy was done by Heissig (1978) and Ziegler \& Fahlbusch (1986).

2. Langenau 1: During the construction of the A7 highway in 1976, a new fossiliferous locality [N 48 29'07.908" E $\left.10^{\circ} 05^{\prime} 58.645^{\prime}\right]$ was found from the Lower Miocene (Ottnangian) in the surroundings of Langenau. It is a trench cut. According to Böttcher (1987), it was possible to recognize, in descending order, three superimposed strata: 1. The "upper fossiliferous layer" ("Obere Fundstelle") corresponds to a yellowish to greyish marl with intercalated gravel layers; 2. the "black layer" ("schwarze Schicht"); and 3. the "yellow layer" ("gelbe Schicht"), which consists of a yellow to brownish fossiliferous sandy marl of unknown thickness. Chameleons came from the second layer, and their occurrence in this locality was mentioned in Sach \& Heizmann (2001); however, the find was never described. The "black layer", up to $2 \mathrm{~m}$ thick, is made of a dark blueish to black, partly pyritized clay, channelling into the subjacent layer. It is rich in vertebrate remains, for example fishes (Gaudant 2006) and amphibians (Böttcher 1987). It has also yielded some complete, though rather poorly preserved, articulated skeletons of Clupeonella 


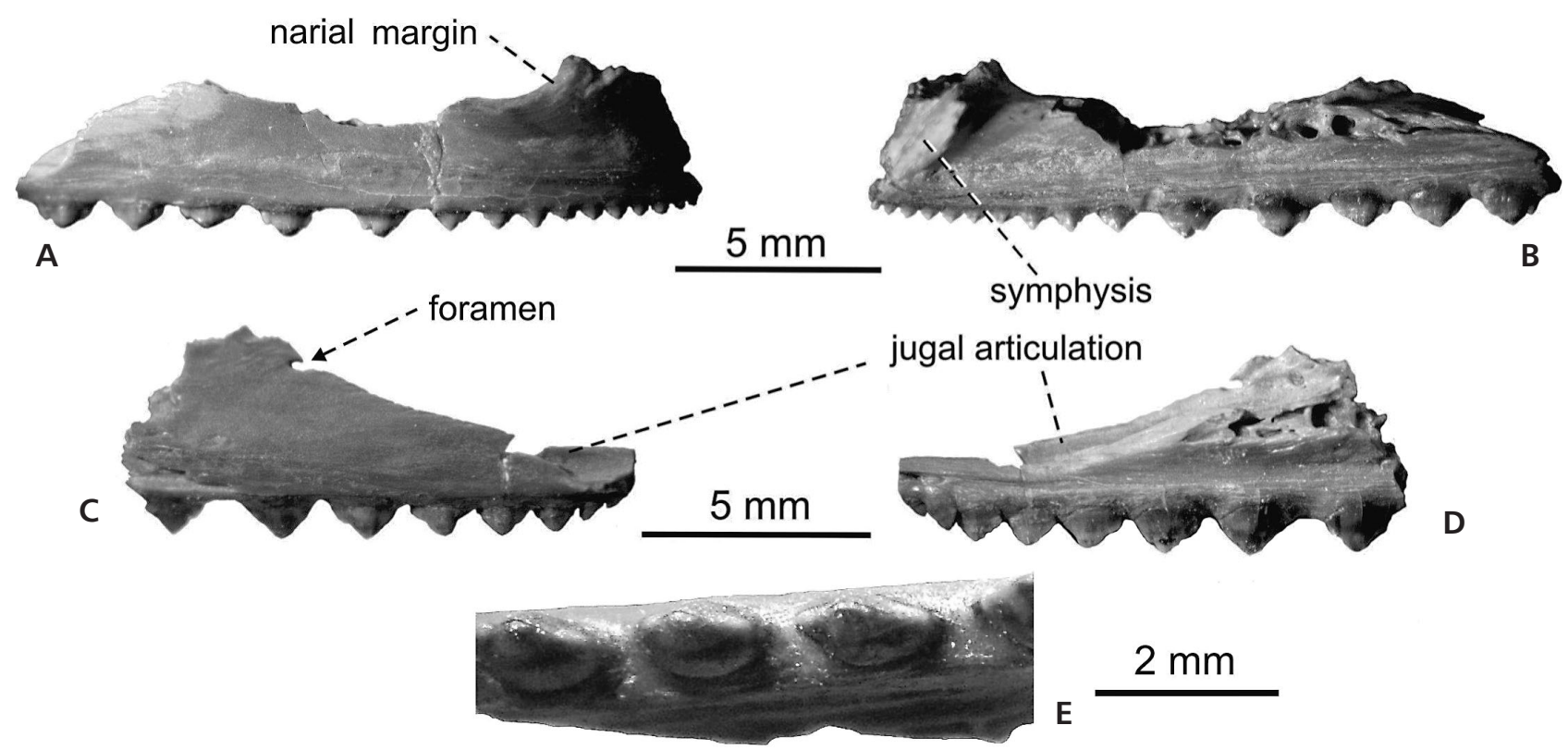

Figure 2. The material of chamaeleonid from the locality of Langenau SMNS $80621 \cdot \bullet A-$ right maxilla in lateral view. $\bullet$ B - in medial view. $\bullet$ C - posterior region of left maxilla in lateral view. $\bullet \mathrm{D}$ - in medial view. $\bullet \mathrm{E}$ - maxillary teeth in larger specimen - detail from the ventral view.

humilis (Von Meyer) (Martini 1983). The fossiliferous strata excavated at Langenau 1 belong to the Lower Miocene and more precisely to the MN4b mammal zone (Heizmann et al. 1980, Sach \& Heizmann 2001). They were deposited in a river flowing south into the brackish sea represented by the "Kirchberg-Schichten" (Böttcher 1987).

3. Wannenwaldtobel 2: This locality consists of an outcrop on the western slope of the Umlach rivulet, $c a 2 \mathrm{~km}$ south-west of Fischbach, $c a 10 \mathrm{~km}$ south of Biberach a.d. Riss, Baden-Württemberg, South Germany. The bed that yielded the vertebrate remains is called Wannenwaldtobel 2 [N 48 01' 54.257”E 9 50’ 05.250`] (Ziegler et al. 2005). This bed is only $0.3 \mathrm{~m}$ thick and dips slightly towards the west. It consists of light-to medium-gray marl, which is only reinforced in the western part. It passes down into calcareous sandy marl clay. The layer of Wannenwaldtobel 2 belongs to the post-lithostratigraphical units in "Brockhorizon" in this area. The fauna from the "Brockhorizont" belongs to the transitional period MN 5/6 (latest Orleanian to earliest Astaracian) (Sach 1999). The locality yielded remains of fishes (Sach et al. 2003) and mammals (Sach 1999). The occurrence of chameleons in this locality was mentioned in Sach (1999) or Böhme (2010); however, the material was never described or figured.

Abbreviations of repositories. - DE - Collection of Department of Ecology, Comenius University, Bratislava, Slovakia; SMNS - the Staatliches Museum für Naturkunde Stuttgart in Germany; BSP number - the Bayerische Staatssammlung für Paläontologie und historische Geologie in Munich.

\section{Systematic palaeontology}

Order Squamata Oppel, 1811

Family Chamaeleonidae Gray, 1825

\section{Chamaeleonidae indet. 1}

Figure 2

Locality and horizon. - Langenau; the Lower Miocene (Orleanium), zone MN 4b.

Material. - Fragment of right maxilla and posterior region of left maxilla (all material prefixed by SMNS 80621).

Description. - The specimens are fragmentary. The description is based on the incomplete right maxilla and posterior portion of the left maxilla (Fig. 2). The bone is a rather elongated and relatively massively built with a slight medial curvature at its anterior end. The nasal process (pars nasalis) is broken and missing. The anteroventral narial margin is only preserved. In the anterior portion, a prominent medial horizontal expansion (the palatine process of the maxilla) is preserved. It continues along the entire length. Unfortunately, it is mostly broken posteriorly. An essentially straight supradental shelf supports a single row of at least 15 tricuspid, acrodont teeth (15 teeth are present in the right maxilla and 8 teeth in the posterior region of the left maxilla). Dorsally, the posterior portion bears the concave articulation area with the jugal. The labial surface of the maxilla is smooth, pierced only in the posterior region by one labial foramen (Fig. 2C). 

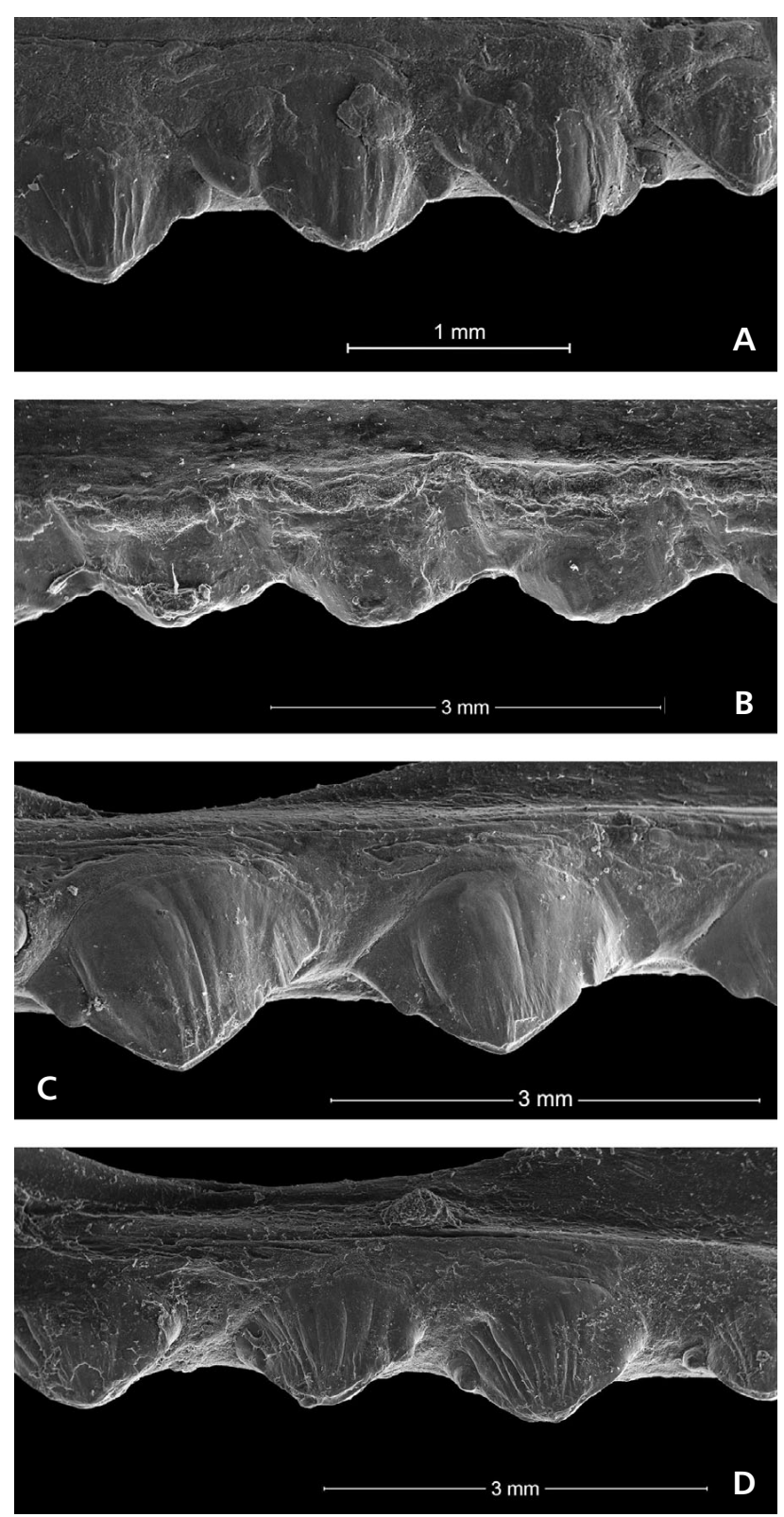

Figure 3. Comparison of the teeth on left maxilla in medial view in A - Chamaeleo chamaeleon; B - Chamaeleo calyptratus; C - Calumma globifer; D - Furcifer pardalis.

Dentition. - All of the teeth are acrodont, with no evidence of a pleurodont implantation. The five most posterior teeth of the dental series in the right maxilla are far more strongly developed than the remainder, which diminish in size anteriorly. However, its posterior end is broken and missing. In the posterior region of the left maxilla, it is possible to see that the tooth size in this portion decreases, and the last two teeth are very small. The teeth are tricuspid, with the central cusp being about twice the size of its mesial and distal accessory cusps, with the former cusp being slightly smaller than the latter. The teeth are compressed medio-laterally. The sizes of inter-dental gaps are small in the anterior region and distinctly widen posteriorly. On the posterior region of the left maxilla, the size of inter-dental gaps decreases again. Weak radial striations are present, mostly on the apical parts of the tooth crowns. The long axis of the tooth is slightly oblique to the jaw axis.

Remarks. - The material from the locality Langenau is identical to that of the species Chamaeleo pfeili Schleich, 1984 (p. 98, fig. 1-4, p. 103, pl. 1, figs 1-7), described from the locality Rauscheröd/Niederbayern, whose deposits represent the same age as the deposits in Langenau. The morphological features common to these fossils are represented especially by large interdental gaps and weak radial striations of the bigger teeth. Schleich (1984) determined that the weak radial striations born by the apical parts of the bigger teeth are diagnostic of this species (see pl. 1, figs 4-7 in Schleich 1984). In Recent chameleons, the anterior region of a maxilla bears 10 small teeth and their size increase distinctly posteriorly usually from $11^{\text {th }}$ tooth (pers. obs). Comparison here shows that the weak radial striations in the bigger teeth are presented in a lot of species of chameleons, e.g. $\mathrm{Ca}$ lumma globifer (Fig. 3C), Furcifer pardalis and Chamaeleo chamaeleon (Fig. 3A). Its intensity is variable even in one specimen. The strongly developed striations of the apical parts of maxillary teeth are also present on the material described from the Merkur-North locality (pl. 1, figs 1, 2 in Fejfar \& Schleich 1994). Here, data on the maxilla are presented for four extant and one fossil species of chameleon:

1. Calumma globifer: this taxon has around 17 maxillary teeth (16 in juvenile individual DE 85; 17 in DE 83; and 18 in DE 84). The biggest one is $3^{\text {rd }}$ tooth from the posterior end, the last is much smaller. Significant striations of the apical parts of the bigger teeth are present (Fig. 3C). The sizes of the inter-dental gaps of the bigger teeth are roughly half those of the tooth bases (Fig. 4C).

2. Furcifer pardalis: In this taxon, the number of maxillary teeth is around 20 and the biggest tooth is approximately the $4^{\text {th }}$ (in DE 80 ) from the posterior end, or the last in DE 81. In this specimen, the number of teeth is 19. Significant strong striations of the most parts of the bigger teeth are present (Fig. 3D). The tooth bases of the bigger teeth are not in contact (Fig. 4D).

3. Chamaeleo chamaeleon: This specimen has 18 maxillary teeth (DE 66). The biggest one is the $6^{\text {th }}$ tooth from the posterior end. Significant striations of the apical parts of the bigger teeth are present (Fig. 3A). The sizes of the inter-dental gaps are small, and the tooth bases are nearly in contact. In the most cases, the more anteriorly situated teeth overlap the base of the next-most posterior tooth, because of oblique orientation of the teeth. This makes imbricate alignment of the teeth (Fig. 4A).

4. Chamaeleo calyptratus: In specimen DE 67, the number of maxillary teeth is 21 and the biggest is $3^{\text {rd }}$ tooth 

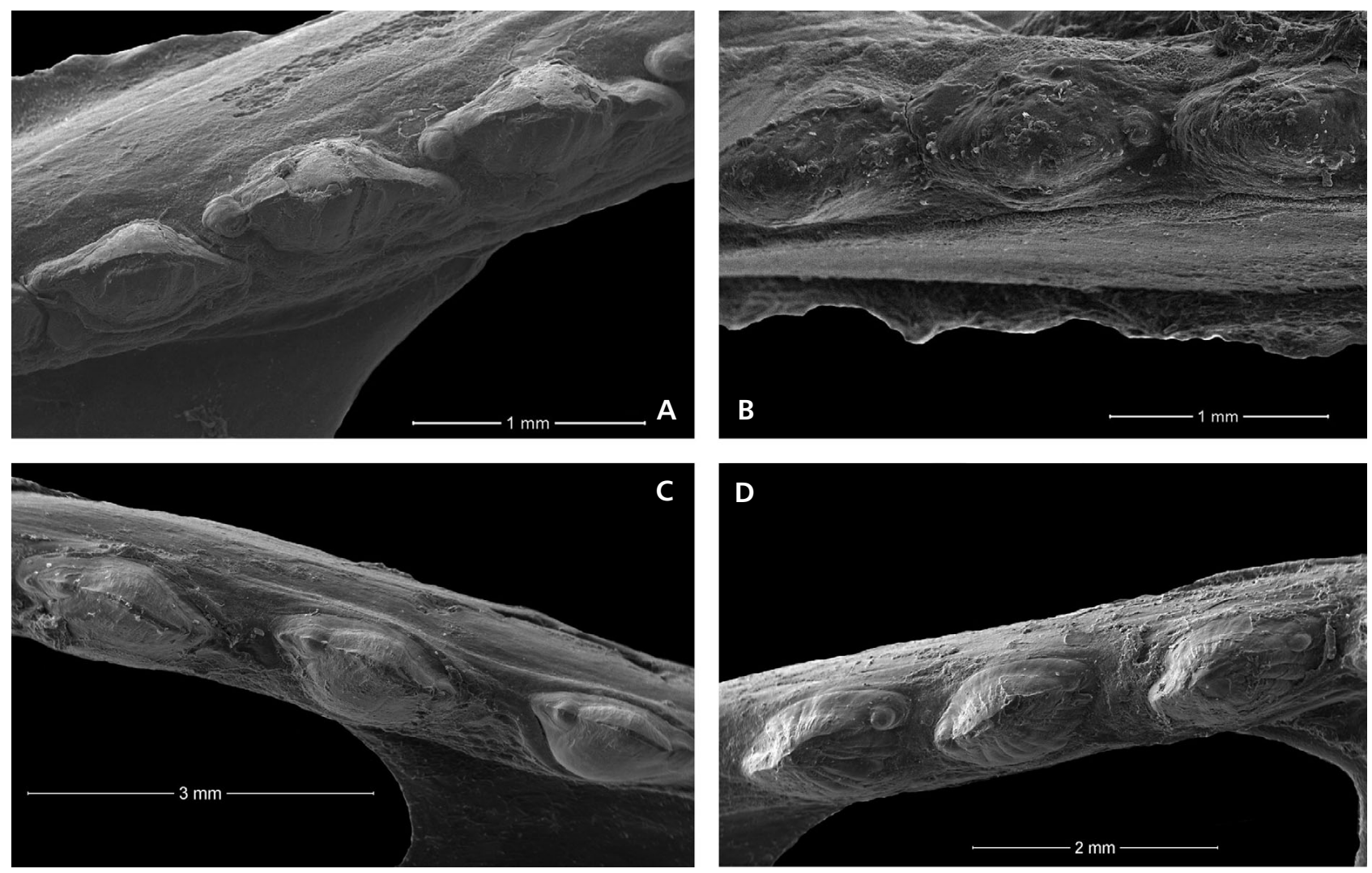

Figure 4. Comparison of the maxillary teeth in ventral view of A - Chamaeleo chamaeleon - right maxilla; B - Chamaeleo calyptratus - right maxilla; $\mathrm{C}-$ Calumma globifer - right maxilla; D - Furcifer pardalis - left maxilla.

from the posterior end. The radial striations of apical parts are lacking (Fig. 3B), or only very poorly developed (in DE 75). Conversely, the total lacking of the striations could be caused by teeth wear in this case (Blain, pers. com.). Unfortunately, the teeth wear is very strong in every specimen of this taxon observed here (except of DE 75). In specimens DE 74 and DE 76, the number of teeth is 18. Here, the biggest teeth are approximately in the middle region of the tooth series. The sizes of the inter-dental gaps are small, tooth bases are in contact. The tooth alignment is in one line (Fig. 4B). In specimen DE 75, the number of teeth is 19 . Here, the imbricate alignment of the last teeth is present too.

5. Chamaeleo pfeili: The first 10 teeth, situated in the anterior region of the maxilla, are small. Their size increases distinctly posterior to the $11^{\text {th }}$ tooth. The significant striations of the apical parts of the bigger teeth are present. The teeth number is 11 on biggest maxillary fragment described by Schleich (1984) and 15 in the material described here. Unfortunately, neither of them is completely preserved. Therefore, we have no exact knowledge about the number of the maxillary teeth. The sizes of the inter-dental gaps of the bigger teeth are roughly half those of the tooth bases (Fig. 2E).

The material described by Schleich as a new species of the genus Chamaeleo, C. pfeili, lacks autapomorphic characters. The only proposed diagnostic feature - striated tooth crowns - is also seen in Calumma globifer and C. chamaeleon, among examined species. For this reason I consider this name as a nomen dubium. In fact, it is difficult even to prove attribution of that fragmentary material to the genus Chamaeleo.

\section{Chamaeleonidae indet. 2}

Figure 5

Locality and horizon. - Petersbuch 2; the Lower Miocene (Orleanium), zone MN 4a.

Material. - Fragment of right dentary and anterior region of right dentary (all material cataloged as SMNS 57885).

Description. - This dentary material is very fragmentary. The dentary gradually increases in height posteriorly. There is a series of rough-surfaced, antero-ventrally oriented, interdental grooves on the labial surface of the jaw parapet. On the lingual side, a well-developed dental groove is situated below the parapet. The most prominent feature on the lingual side of the dentary is a deep Meckel's groove (sulcus Meckeli) (Fig. 5A, C), which is roofed by a welldeveloped supraalveolar ridge and floored by a slightly 


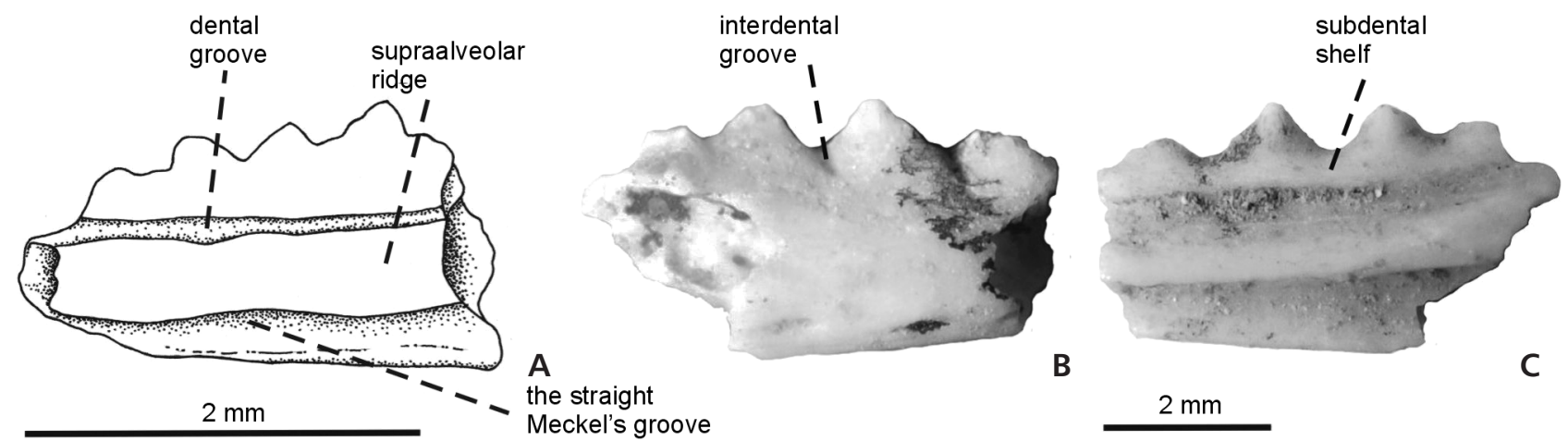

Figure 5. Chamaeleonidae indet. 2 from the locality Petersbuch 2 SMNS 57885. $\bullet$ A - anterior region of right dentary in medial view. $\bullet$ B - right dentary in lateral; and $\mathrm{C}$ - medial views.

thickened ventral edge (crista ventralis) along its entire length. The Meckel'groove continues anteriorly, most likely directly across the lower portion of the symphysis (Fig. 5A). The supraalveolar ridge is well developed and widens a little bit posteriorly.

Dentition. - All of the teeth are acrodont, with no evidence of a pleurodont implantation.

Remarks. - The morphology of the Petersbuch 2 material is very similar to that of the chameleons described from the Czech Republic (Moody \& Roček 1980, Čerňanský 2010). The Czech material can be divided into two dentary morphotypes. In the first the symphysis is oval, the anterior end of the Meckel'groove of the dentary turns ventrally, and the crista ventralis continues dorsally and crosses the supraalveolar ridge close to the symphysis (penetration of the symphysial region can only be seen in the ventral view. Here, on the ventral side, the Meckelian groove continues only as a shallow furrow and it is not bordered ventrally). This type of dentary morphology can be seen in many recent chamaeleons, e.g. C. calyptratus and Calumma globifer. The second type has a square symphysis, and the anterior end of the Meckel'groove is straight and penetrates the lowermost portion of the symphysis in the medial view. This type can be seen in the recent species C. chamaeleon (see Čerňanský 2010), for example. The material from Petersbuch 2 has a straight Meckelian groove. From the medial view, it is possible to see that the lowermost portion of the symphysis was most likely penetrated by the Meckel's groove (Fig. 5A). However, data about the shape of the symphysial facet are missing because this structure is not preserved.

\section{?Chamaeleonidae indet. 3}

Figure 6

Locality and horizon. - Wannenwaldtobel; the Middle Miocene, zone MN 5/6.
Material. - Fragment of right maxilla, prefixed by SMNS 85709.

Description. - The maxilla is very fragmentary. Just two acrodont, slightly tricuspid teeth are present here (Fig. 6). The fragment is likely to have come from the relatively huge and massively built maxilla. Except for the anteroposteriorly oriented shallow grooves above the teeth, the rest of the labial surface of the preserved portion of the bone is smooth.

\section{Discussion and conclusion}

The material, which was described by Schleich (1984) as a new species Chamaeleo pfeili, is only fragmentary preserved. There, only the incomplete maxillae are known. As described above, the maxilla of this taxon has the following significant features: 1) the presence of weak radial striations on apical parts of bigger teeth; 2) the tooth bases of the bigger teeth are not in contact. However, e.g. the species Calumma globifer compared here, has the same maxillary characters. For this reason, the material described by Schleich (1984) as new species lacks autapomorphic features. There is no legitimate reason, which allows to describe this material as a new species. Therefore, this taxon is species inquirenda and the name C.pfeili is a nomen dubium.

Unfortunately, the material described here from the locality Wannenwaldtobel lacks anteriorly situated teeth. In contrast with chamaeleonids, agamids retain a trace of the primitive pleurodont condition (often in caniniform anterior teeth) by ankylosing their teeth slightly towards the lingual side of the jaw rather than directly on the jaw edge (Moody 1978, Moody \& Roček 1980; “subpleurodont" of Averianov \& Danilov 1996). Based on absence of this formal proof, the attribution of the Wannenwaldtobel material to the family Chamaeleonidae could be questionable. Although the last occurrence of chamaeleonids in central Europe is known from the zone 

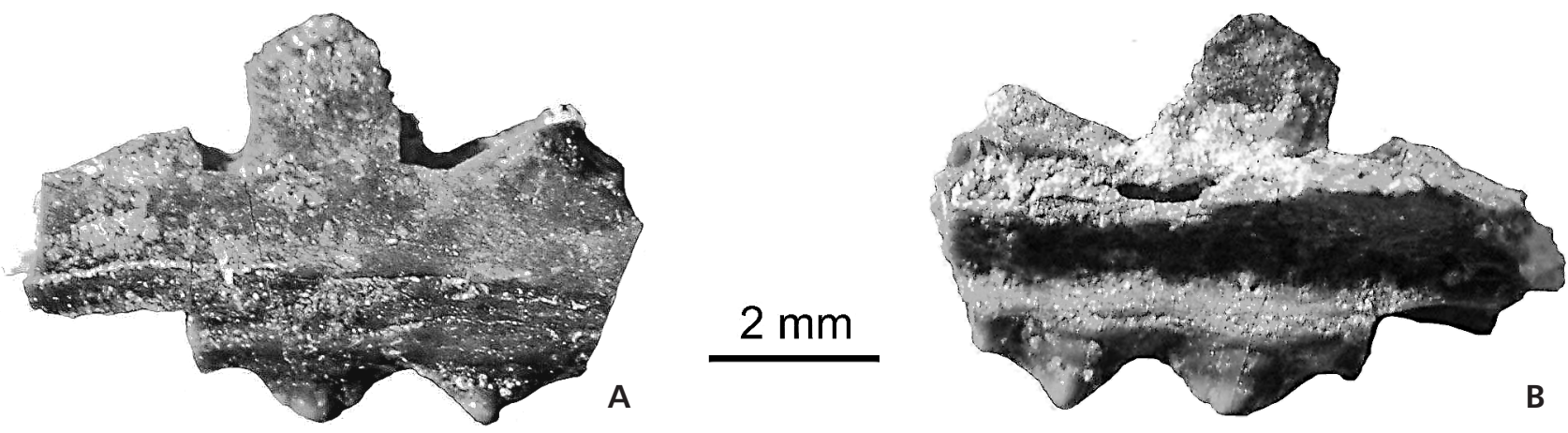

Figure 6. ?Chamaeleonidae indet. 3 from the locality Wannenwaldtobel 2 SMNS 85709: fragment of right maxilla in lateral (A); and in medial views (B).

MN6 (Bolliger 1992), the Wannenwaldtobel material could represent the stratigraphically youngest record of such large chameleonids in Europe. The identification of chameleons using only isolated dentary and maxilla is questionable. All of the chamaeleonids from the European region might have belonged to the genus Chamaeleo, to which genus they are referred. However, it is impossible to demonstrate this based on available material. Within the Recent chameleons, the exact identification of the individual species (or in many cases, even the genus) merely on the basis of the morphology of fragmentary jaw bits is in most cases impossible (Čerňanský 2010). If material lacks autapomorphic features, we can only identify morphotypes. The material of chameleons described here most likely belongs to this genus. However, without the preservation of diagnostic characters, it is better to identify this material as Chamaeleonidae indet.

On base of the comparison study presents here, it seems that tooth bases of chameleons living in closed habitats are not in contact (larger interdental gaps of bigger teeth), while chameleons with wider heads from open habitats have tooth bases in contact or nearly so (imbricate teeth alignment). However, the general applicability of this hypotetical result can only be confirmed or denied by further comparison studies of other taxa. According to Measey et al. (2009), open habitat males had wider heads, biting harder than closed habitat males.

\section{Acknowledgements}

I am indebted to Dr. K. Smith (Forschungsinstitut Senckenberg Frankfurt) for his helpful advices. My thanks belong also to Dr. R. Böttcher (Staatliches Museum für Naturkunde Stuttgart in Germany) for access to the material described in this paper. Dr. V. Šmatko (Slovak Academy of Science in Bratislava) kindly made a photographs using SEM. For critically reading the manuscript and the text corrections I thank Dr. M. Augé (Muséum National D'Histoire Naturelle Paris) and Dr. H.L. Blain (Universitat Rovira i Virgili, Spain). This project was supported by a VEGA grant, number V-09-060-00.

\section{References}

AndReone, F., Guarino, F.M. \& Randrianirina, J.E. 2005. Life history traits, age profile, and conservation of the panther chameleon, Furcifer pardalis (Cuvier 1829), at Nosy Be, NW Madagascar. Tropical Zoology 18, 209-225.

Averianov, A. \& Danilov, I. 1996. Agamid lizards (Reptilia, Sauria, Agamidae) from the Early Eocene of Kyrgyzstan. Neues Jahrbuch für Geologie und Paläontologie, Monatshefte 12, 739-750.

BöHME, M. 2003. The Miocene Climatic Optimum: evidence from ectothermic vertebrates of Central Europe. Palaeogeography, Palaeoclimatology, Palaeoecology 195, 389-401.

DOI 10.1016/S0031-0182(03)00367-5

BÖHME, M. 2010. Ectothermic vertebrates (Actinopterygii, Allocaudata, Urodela, Anura, Crocodylia, Squamata) from the Miocene of Sandelzhausen (Germany, Bavaria) and their implications for environment reconstruction and palaeoclimate. Paläontologische Zeitschrift 84, 3-41. DOI 10.1007/s12542-010-0050-4

Bolliger, T. 1992. Kleinsäugerstratigraphie der miozänen Hörnlischüttung (Ostschweiz). Dokumenta naturae 75, 1-297.

BöTTCHER, R. 1987. Neue Funde von Andrias scheuchzeri (Cryptobranchidae, Amphibia) aus der süddeutschen Molasse (Miozän). Stuttgarter Beiträge zur Naturkunde, Serie B 131, 1-38.

Brygoo, E.R. 1971. Reptiles Sauriens Chamaeleonidae. Genre Chamaeleo. Faune de Madagascar 33, 1-318. [in French]

ČERŇANSKÝ, A. 2010. A revision of chamaeleonids from the Lower Miocene of the Czech Republic with description of a new species of Chamaeleo (Squamata, Chamaeleonidae). Geobios 43, 605-613. DOI 10.1016/j.geobios.2010.04.001

Chondropoulos, B.P. 1986. A checklist of the Greek reptiles. I. The lizards. Amphibia-Reptilia 7, 217-235.

DOI 10.1163/156853886X00028

Estes, R. 1983. Sauria Terrestria, Amphisbaenia (Handbuch der Paläoherpetologie). 248 pp. Gustav Fischer Verlag, Stuttgart.

FeJfar, O. \& SChleich, H.H. 1994. Ein Chamäleonfund aus dem unteren Orleanium des Braunkohlen-Tagebaus Merkur-Nord (Nordböhmen). Courier Forschungsinstitut Senckenberg 173, 167-173.

Fejfar, O., Rummel, M. \& Tomida, Y. 1998. New eomyid genus and species from the Early Miocene (MN-zones 3-4) of Europe and Japan related to Apeomys (Eomyidae, Rodentia, Mammalia). National Science Museum Monographs 14, 123-143.

FritZ, J.P. \& SChÜTTE, F. 1987. Zur Biologie jemenitischer Chamaeleo calyptratus Duméril \& Duméril, 1851 mit einigen Anmerkungen zum systematischen status (Sauria, Chamaeleonidae). Salamandra 23, 17-25. 
Gasc, J.P., Cabela, A., Crnobrnja-Isailovic, J., Dolmen, D. Grossenbacher, K., Haffner, P., Lescure, J., Martens, H., Martinez Rica, J.P., Maurin, H., Oliveira, M.E., Sofianidou, T. S., Veith, M. \& Zuiderwijk, A. 1997. Atlas of Amphibians and reptiles in Europe. 494 pp. Societas Europaea Herpetologica, Museum National d'Histoire Naturelle.

Gaudant, J. 2006. Occurrence of skeletal remains of Channids (Teleostean Fishes) in the Ottnangian (Lower Miocene) of Langenau, near Ulm (Württemberg, Germany). Stuttgarter Beiträge zur Naturkunde 361, 1-15.

GLAw, F. \& VENCES, M. 1994. A fieldguide to the amphibians and reptiles of Madagascar, $2^{\text {nd }}$ edition. $480 \mathrm{pp}$. Cologne, Vences \& Glaw Verlag.

HeIssig, K. 1978. Fossilführende Spaltenfüllungen Süddeutschlands und die Ökologie ihrer Huftiere. Mitteilungen der Bayerischen Staatssammlung für Paläontologie und historische Geologie 81, 237-288.

Heizmann, E.P.J. 1983. Die Gattung Cainotherium (Cainotheriidae) im Orleanium und im Astaracium Süddeutschlands. Eclogae Geologicae Helvetiae 76, 781-825.

Heizmann, E.P.J., Ginsburg, L. \& Bulot, C. 1980. Prosansanosmilus peregrinus, ein neuer machairodontider Felide aus dem Miozän Deutschlands und Frankreichs. Stuttgarter Beiträge zur Naturkunde, Serie B 58, 1-27.

Hillenius, D. 1959. The differentiation within the genus Chamaeleo Laurenti, 1768. Beaufortia 8, 1-92.

HiLlenius, D. 1978. Notes on chameleons V. The chameleons of North Africa and adjacent countries, Chamaeleo chamaeleon (Linnaeus) (Sauria, Chamaeleonidae). Beaufortia 28, 37-55.

Kosma, R. 2004. The dentition of recent and fossil Scincomorphan lizards (Lacertilia, Squamata) - Systematics, Functional Morphology, Palaeoecology. 187 pp. Unpublished Ph.D. thesis, University of Hannover.

Krysko, K.L., Enge, K.M. \& KIng, F.W. 2004. The veiled chameleon, Chamaeleo calyptratus, a new exotic lizard species in Florida. Florida Scientist 67, 249-253.

Martini, E. 1983. Die Fischfauna von Langenau bei Ulm (UnterMiozän, Ottnang-Stufe). Stuttgarter Beiträge zur Naturkunde, Serie B 91, 1-25.

Measey, G.J., Hophins, K. \& Tolley, K.A. 2009. Morphology, ornaments and performance in two chameleon ecomorphs, is the casque bigger than the bite? Zoology 112, 217-226. DOI 10.1016/j.zool.2008.09.005

Meerman, J. \& Boomsma, T. 1987. Beobachtungen an Chamaeleo calyptratus calyptratus Duméril \& Duméril, 1851 in der Arabischen Republik Jemen (Sauria, Chamaeleonidae). Salamandra 23, 10-16.

Moody, S. 1978. The phylogenetic relationships of taxa within the lizards family Agamidae. Doctoral dissertation manuscript, University of Michigan at Ann Arbor.

Moody, S. \& RočEK, Z. 1980. Chamaeleo caroliquarti (Chamaeleonidae, Sauria), a new species from the Lower Miocene of central Europe. Věstník Ústředního ústavu geologického 55, 85-92.

Mörs, T. 2002. Biostratigraphy and paleoecology of continental Tertiary vertebrate faunas in the Lower Rhine Embayment (NW-Germany). Netherlands Journal of Geosciences/Geologie en Mijnbouw 81, 177-183.

OndRIAS, J.C. 1968. Liste des amphibiens et des reptiles de la Grece. Biologica Gallo-Hellenica 1, 111-135.

RiepPel, O. \& CRumly, C. 1997. Paedomorphosis and skull structure in Malagasy chamaeleons (Reptilia, Chamaeleoninae). Journal of Zoology 243, 351-380. DOI 10.1111/j.1469-7998.1997.tb02788.x
SACH, V. 1999. Litho- und biostratigraphische Untersuchungen in der Oberen Suswassermolasse des Landkreises Biberach a.d. Ris (Oberschwaben). Stuttgarter Beiträge zur Naturkunde 276, $1-167$.

Sach, V. \& HeizmanN, E.P.J. 2001. Stratigraphie und Säugetierfaunen der Brackwassermolasse in der Umgebung von Ulm (Südwestdeutschland). Stuttgarter Beiträge zur Naturkunde, Serie B 310, 1-95.

Sach, V., Gaudant, J., Reichenbacher, B. \& Böhme, M. 2003. Die Fischfaunen der Fundstellen Edelbeuren-Mauerkopf und Wannenwaldtobel 2 (Miozän, Obere Süßwassermolasse, Süddeutschland). Stuttgarter Beiträge zur Naturkunde, Serie B 334, 1-25.

SCHLEICH, H.H. 1983. Die mittelmiozäne Fossil-Lagerstätte Sandelzhausen. 13. Chamaeleo bavaricus sp. nov., ein neuer Nachweis aus dem Jungtertiär Süddeutchlands. Mitteilungen der Beyerischen Staatssamlung für Palaeontologie und Historische Geologie 23, 77-81.

SCHLEICH, H.H. 1984. Neue Reptilienfunde aus dem Tertiär Deutschlands 2. Chamaeleo pfeili sp. nov. von der untermiozänen Fossilfundstelle Rauscheröd/Niederbayern (Reptilia, Sauria, Chamaeleonidae). Mitteilungen der Bayerischen Staatssamlung für Palaeontologie und Historische Geologie 24, 97-103.

SCHLEICH, H.H. 1994. Neue Reptilfunde aus dem Tertiär Deutschlands. 15. Neue Funde fossiler Chamäleonen aus dem Neogen Süddeutschlands. Courier Forschunginstitut Senckenberg 173, 175-195.

Schmidt, W. 2001. Chamaeleo calyptratus, the Yemen Chameleon. 79 pp. Matthias Schmidt Publ. Natur und Tier-Verlag, Berlin.

SHOwlER, D. 1995. Reptile observations in Yemen, March-May 1993. British Herpetology Society Bulletin 53, 13-23.

Szyndlar, Z. \& Schleich, H. 1993. Description of Miocene snakes from Petersbuch 2 with comments on the Lower and Middle Miocene ophidian faunas of southern Germany. Stuttgarter Beiträge zur Naturkunde 192, 1-47.

TAlAVERA, R. \& SANChIZ, F. 1983. Restos holocénicos de Camaleón común, Chamaeleo chamaeleon (L.) de Málaga. Boletin de la Real Sociedad Española de Historia Natural (Geologia) 81, 81-84.

Wu, W. 1993. Neue Gliridae (Rodentia, Mammalia) aus untermiozänen (orleanischen) Spaltenfüllungen Süddeutschlands. Documenta naturae 81, 1-149.

ZARI, T.A. 1993. Effects of body mass and temperature on standard metabolic rate of the desert chameleon Chamaeleo calyptratus. Journal of Arid Environments 24, 75-80. DOI 10.1006/jare.1993.1006

ZIEGLER, R. 1985. Talpiden (Mammalia, Insectivora) aus dem Orleanium und Astaracium Bayerns. Mitteilungen der Bayerischen Staatssammlung für Paläontologie und historische Geologie 25, 131-175.

ZIEGLER, R. 1989. Heterosoricidae und Soricidae (Insectivora, Mammalia) aus dem Oberoligozän und Untermiozän Süddeutschlands. Stuttgarter Beiträge zur Naturkunde 154, 1-73.

ZIEGLER, R. 1990. Didelphidae, Erinaceidae, Metacodontidae und Dimylidae (Mammalia) aus dem Oberoligozän und Untermiozän Süddeutschlands. Stuttgarter Beiträge zur Naturkunde 158, 1-99.

ZIEGLER, R. \& FAHLBUSCH, V. 1986. Kleinsäuger-Faunen aus der basalen Oberen Süßwasser-Molasse Niederbayerns. Zitteliana 14, 3-80.

Ziegler, R., Dahlmann, T., Reumer, J.W.F. \& Storch, G. 2005. Germany. Scripta Geologica, Special Issues 5, 61-98. 